
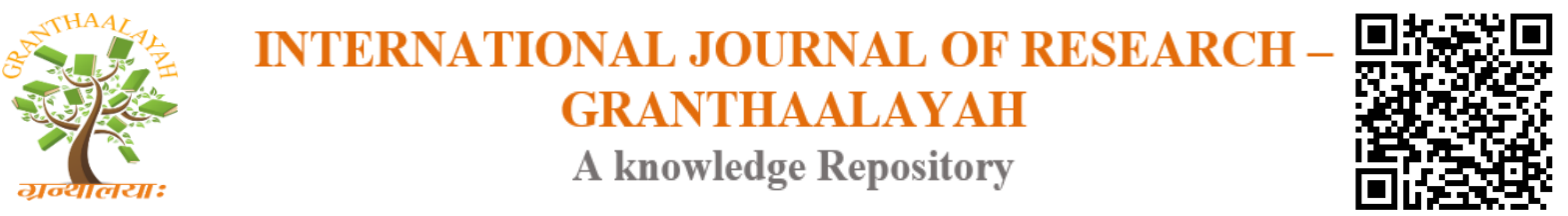

Science

\title{
INTEGRATED MANAGEMENT OF CHOCOLATE SPOT (BOTRYTIS FABAE) DISEASE OF FABA BEAN (VICIA FABA L.) IN ETHIOPIA: A REVIEW
}

\author{
Misgana Mitiku *1 \\ ${ }^{* 1}$ Department of Plant Pathology, Southern Agricultural Research Institute, Jinka Agricultural \\ Research Center, P.O. Box 96, Jinka, Ethiopia
}

\begin{abstract}
The primary producers of pulses are small-scale farmers with small and dispersed plots under rain-fed conditions with substantially lower yields of less than 0.9 t/ha as compared to the improved faba bean varieties and international yields. There are many biotic and abiotic factors which hampers faba bean production in Ethiopia. From biotic factors chocolate spot (Botrytis fabae Sard.) is the major fungal disease hampering faba bean production in Ethiopia.). It is a highly prevalent and destructive disease, causing yield loss up to $61 \%$ on a susceptible and $34 \%$ on tolerant faba bean genotypes in the central highlands. But we can manage this economically important disease in manner which comprises all available diseases management methods in combination that is IPM (Integrated Pest management). So, the objective of this review work was to review available integrated pest management option for management of chocolate spot disease of faba bean in Ethiopia. We can control the disease by using different methods from these late sowing of faba bean, mixed cropping of faba bean with cereal crops and mancozeb spray reduced the disease and increased the grain yield and seed weight over sole and mixed cropping with field pea; also cereal mixing with faba bean has advantages over faba bean mixing with field pea. Suppressive effects can be ascribed to a combination of host biomass reduction, altered microclimate and physical barriers to spore dispersal. Also creation of a physical barrier in the form of non-host plants prevents some of the dispersed spores from being deposited on the host tissue by interception. In Ethiopia, study has revealed that the biological control agents for chocolate spot of faba bean and Bacilli are natural residents of faba bean leaves. Additionally recommendation have been given that, further study has to be done to explore the mode of action by bacillus subtilis against fabae.
\end{abstract}

Keywords: Faba Bean; Botrytis Fabae Sard; Chocolate Spot; Bacillus Subtilis and IPM.

Cite This Article: Misgana Mitiku. (2017). "INTEGRATED MANAGEMENT OF CHOCOLATE SPOT (BOTRYTIS FABAE) DISEASE OF FABA BEAN (VICIA FABA L.) IN ETHIOPIA: A REVIEW." International Journal of Research - Granthaalayah, 5(9), 195-205. https://doi.org/10.29121/granthaalayah.v5.i9.2017.2231. 


\section{Introduction}

The faba bean (Vicia faba L.) in Ethiopia locally known as "Bakela" has been grown in the highlands of Ethiopia between 1800 and $3000 \mathrm{~m}$ above sea level. For many decades and the country is now considered as one of the centers of secondary diversity for the crop [3]. The crop occupies the largest areas among legumes and the total area under cultivation is estimated to be about 443,107.88 ha from which 8,389,438.97 quintals of grain yield is harvested [6]. The primary producers of pulses are small-scale farmers with small and dispersed plots under rainfed conditions with substantially lower yields of less than $0.9 \mathrm{t} /$ ha as compared to the improved faba bean varieties and international yields. There are many biotic and abiotic factors which hampers faba bean production in Ethiopia. From biotic factors chocolate spot (Botrytis fabae Sard.) is the major fungal disease hampering faba bean production in Ethiopia [14, 24]. It is a highly prevalent and destructive disease, causing yield loss up to $61 \%$ on a susceptible and $34 \%$ on tolerant faba bean genotypes in the central highlands [14]. [24] Reported even higher losses of $67.5 \%$ in the unsprayed faba bean plots in northwest Ethiopia.

The production of the crop is enormously declining as the local faba bean cultivars are entirely attacked by chocolate spot and other diseases in southwest Ethiopia [23]. But we can manage this economically important diseases in manner which comprises all available diseases management methods in combination that is integrated management of diseases (IDM) which is synonymous to IPM(Integrated Pest management). So, the objectives of this work were to review available integrated pest management option for management of chocolate spot disease of faba bean and to point out the gaps in this area.

\section{Literature Review}

\subsection{Faba Bean}

The faba bean (Vicia faba) is belonging to tribe Vicieae. Herbs with pinnate leaves and grows upright, ranging from 1-1.5 meters tall. It is an annual legume with one or more strong, hollow and erect stems. Faba bean has a strong taproot, compound leaves, and large, white flowers with dark purple marking. A flower cluster may produce 1-4 pods. The pods are large (up to $10 \mathrm{~cm}$ long and 1-2 cm wide) and green, turning dark at maturity.

Three to four oblong/oval seeds are contained within each pod. Flowering occurs in 45-60 days and requires 87-176 days to mature [1].According to [19] faba bean (Vicia faba) is classified into two subspecies paucijuga and eu-faba. Three varieties are recognized within eu-faba, the large seeded var. major, the intermediate var.equina, and the small seeded var. minor. Although Vicia faba was originated in the Mediterranean-Near East region, it is a temperate crop in its adaptation and has similar requirement with other pulse crops in the tribe Vicieae. It is a legume capable of fixing nitrogen in association with root nodule bacteria and it is the most efficient nitrogen fixer of the pulse crops [1].

However, this crop is one of the earliest domesticated food legumes and is now cultivated on large areas in many countries due to its high nutritive value in terms of energy and protein contents (24-30\%). China leads in production, followed by Ethiopia, Egypt, Italy and Morocco. The crop occupies the largest area among the pulses in Ethiopia. Even though Ethiopia is the 
world's second largest producer of faba bean, its share is only $6.96 \%$ of world production and $40.5 \%$ of Africa due to numerous diseases and other a biotic factor that affect the faba bean production and productivity. Therefore, increasing the crop production through using appropriate diseases management is one of the most important targets of agricultural policy in Ethiopia.

\subsection{Economic Importance of the Disease}

Chocolate leaf spot is caused by both Botrytis cinerea Pers. ex Pers. and Botrytis fabae Sard. A teleomorph of B. fabae, Botryotinia fabae, was described by [26]. B. cinerea is a parasite and saprophyte on a wide range of host plants, whereas $B$. fabae is specialized for the invasion and colonization of Vicia spp. especially V. faba. The existence of races of B. faba has been proposed on the basis of reaction to differentials in Mediterranean countries. More works have to be done to understand variability in B. fabae. Chocolate spot, caused by Botrytis fabae, is one of the major diseases of faba bean nationwide [5, 13]. [9] Recorded yield loss of up to $61 \%$ for susceptible genotypes and $34 \%$ for tolerant genotypes. Yet complete crop failure due to the disease is commonly encountered when a long lasting favorable environmental condition for disease development prevails in an area [15]. In Negash areas, Tigray, in 2000 seed yield loss of $62 \%$ was due to this disease.

\subsection{Ecology and Epidemiology}

The pathogen infects the leaf tissue, petioles, stems and seeds [11]. It survives as sclerotia in infected plant debris for more than a year. According to [11] sclerotia of B. fabae stay alive for about two years under Holetta conditions on the surface of the ground and die in four months when buried $20 \mathrm{~cm}$ deep. The fungus B.fabae was recovered from infected plant debris stored in Nitosol after 12 months, But not from that stored in Vertisol [13]. Apparently, soil type and depth at which infected plant residues are located have an effect on the biology of the fungus, and this might have practical implication on disease management.

Humid ( $\geq 70 \%$ relative humidity, especially in the mornings), warm $\left(10-23^{\circ} \mathrm{C}\right)$ and rainy (frequent rain) weather conditions are favorable for the growth of chocolate spot epidemic [10]. With this environment, the epidemic grows with the apparent infection rates ranging from 0.142 to 0.164 disease unit per day, which means several chocolate spot generations within a single growing season [10].This is an indication to rapid and dangerous spread of the disease. Obviously, if the pathogen falls short of the above listed weather variables, it will be forced to have short infection period, and this is significant in spread of an epidemic.

\section{Control of the Disease}

\subsection{Integrated Pest Management (IPM) or Integrated Disease Management (IDM)}

The main emphasis in research and development to combat food legume diseases is on host resistance and chemical control where ever applicable, and quite often these components of disease management were practiced in isolation to each other. Recently a shift in scientific thinking and practice in the management of faba bean diseases has been seen and greater 
emphasis was on identifying, evaluating, and integrating location specific components of integrated disease management (IDM). Integrated Pest management has been defined in many ways. One widely used definition was formulated by the United States Department of Agriculture in 1996, stating that IPM is " a sustainable approach to managing pests by combining biological, cultural, physical, and chemical tools in a way that minimizes economic, health, and environmental risks" or integrated pest management is a process we can use to solve pest problems while minimizing risks to people and the environment. IPM can be used to manage all kinds of pests anywhere in urban, agricultural, and wild land or natural areas.

The word "pests", in this definition, includes diseases and weeds as well as animals. The list of management tools often also includes genetics, i.e., resistant cultivars, and some definitions specify lack of impact on non-target organisms or mention maximizing the benefits as well as minimizing the risks. Further key aspects of IPM are the understanding of the biology of the pest, in order to model and predict outbreaks, and the concept of thresholds of damage, at which it becomes economically worthwhile to apply control methods. An individual management practice may not reduce the level of disease to an acceptable level, whereas the additive effect of several practices will be done. An integrated approach is the key to successful management of chocolate spot in faba bean. In general IDM has followed the principles of IPM [19]. The location specific IDM of faba bean is primarily based on host plant resistance (HPR) or genetic resistance; additionally other components of diseases management.

In some environments, IDM may require a single component used alone (usually HPR) or in combination with one other component (such as fungicide seed treatment) to adequately combat diseases of faba bean. The components of IDM employed in the production of faba bean are listed as follows:

- Cultural (agronomic) practices (sowing dates, plant population etc.).

- Host plant resistance (HPR),

- Biological control

- Chemical sprays (fungicides, pesticides),

- Disease modeling (prediction) for avoidance of high risk or disease pressure,

The combination of genetic resistance, hygiene and monitoring of crops for threshold levels of infestation, allows the most economic and effective controls with the result that economic yields can be maximized.

Table1: Progress in integrated chocolate spot management of faba bean

\begin{tabular}{|l|l|l|l|l|l|}
\hline Crop & Disease & Component of IDM/IPM & BC \\
\hline Faba bean & $\begin{array}{l}\text { Chocolate } \\
\text { spot }\end{array}$ & HPR & AP & CC & X \\
\cline { 2 - 4 } & *** & $*$ & $* *$ & x \\
\hline
\end{tabular}

Note:*,**,***=low, medium and High potential respectively; $\mathrm{X}=$ Not common

Source: Jellis et al., 1998

\subsubsection{Cultural Control}

Substantial delay and shortening of chocolate spot epidemic and thereby reduction of attack can be achieved by late sowing of faba bean as the conditions suitable for the development of the 
disease do not exist for a sufficiently long period of time [10]. However, seed yield harvest from the late sown crop is considerably less than that of early sown crop.

Research report done by [16] revealed that, deep plowing of the fields with high chocolate spot infection immediately after harvest reduce the risk of disease development. In addition, early sowing, use of improved cultivars varieties and fungicide (chlorothalonil at a rate of $2.5 \mathrm{~kg}$ a.i. per hectare once or twice after disease infection reached 30\%) avoid the occurrence of chocolate spot disease at epidemic proportions. Another research done by [4, 12] depicted that, planting of faba bean in mixture with field pea in a ratio of 1:2 drastically reduces epidemic development of chocolate spot in faba bean. Studies carried out at several locations in the northwest part of the country by Adet Agricultural Research Center confirmed the advantages of mixing faba bean and field pea in different proportions in reducing chocolate spot severity [1].However, mixed cropping culture might not be feasible in large scale production of faba bean. The value of growing of faba bean in mixture with field pea regarding reduction of chocolate spot infection in faba bean is continuous [17].

\subsubsection{Use of Resistance/Tolerant Varieties or Host Resistance}

Enormous differences exist among local and exotic genotypes with respect to resistance or tolerance $[8,13,16$, and 27] which could be exploited to breed chocolate spot resistant faba bean varieties.

Research done by [23] by using 13 faba bean revealed that in all assessment dates between 35 and 98 DAP chocolate spot severity was significantly lower $(<23 \%)$ on CS20DK and Degaga followed by Tesfa and Bulga-70\%.Also research done by Gebrehiwot, (2011) revealed that faba bean genotypes varied greatly in their resistance. Meanwhile, the resistant genotypes EH000124, EH01046-1, EH00053-1 and EH01021-1 should be further evaluated for their possible use in future for faba bean improvement program. Similarly Faba bean collections have been screened for response to chocolate spot and evaluation methods improved [5]. The International Centre for Agriculture Research in Dry Areas (ICARDA) has incorporated resistance into local germplasm, so new genotypes have been introduced in Australia, Egypt and Ethiopia, among other countries [25]. So far several chocolate spot resistant genotypes have been reported. Source of resistance for chocolate spot (BPL-1179-A-1, BPL-1802-1 and BPL-1179-2) have been identified from introductions of ICARDA to Ethiopia [23]. From the landrace collections, a number of varieties, namely CS20DK, NC-58, Bulga 70 (coll111/77), Wayu (Wayu 89-5), Selale, Lalo, Dagm and Adet Hana have been nationally or regionally released for different recommendation domains [23]. This indicated that there is an opportunity to find resistant varieties in the future which help in increment of faba bean production in Ethiopia as well as it will be incorporated in integrated disease management strategies.

\subsubsection{Biological Control}

There is promise in using biological control agents to control chocolate spot diseases; nevertheless, this strategy has not been fully exploited. Isolate of Trichoderma ovalisporum and Trichoderma longibrachiatum as effective antagonists of B. fabae for the first time [25]. In Ethiopia, study revealed that the biological control agents for chocolate spot of faba bean and Bacilli are natural residents of faba bean leaves. Thirty isolates of Bacillus spp. were tested for 
their effects on $B$. fabae by dual culture technique on potato dextrose agar. Sixteen isolates produced $5 \mathrm{~mm}$ or higher inhibition zone and out of these, two isolates were the most effective having inhibition zone of 8 and $7 \mathrm{~mm}$.

Isolates reduced the growth of the pathogen colony in dual culture by $23-64 \%$. Four Isolates proved most effective in retarding disease development on two susceptible and one tolerant cultivar and can be further explored for commercial use for management of chocolate spot disease of faba bean [24].

Also study which was conducted by Kharrat Mohamed confirmed that Bacillus subtillis which is gram positive and obligate bacteria had role as biological control against B.fabae. What they do was that they grow the causative pathogen alone and together with the antagonist bacteria on the growth media finally the found that the bacillus have greatest potential to control chocolate spot disease of faba bean so, finally they conclude that B. subtili can be further recommended as component of integrated management of chocolate spot disease of faba bean; additionally they recommended that, further study has to be done to explore the mode of action by bacillus subtilis against fabae.

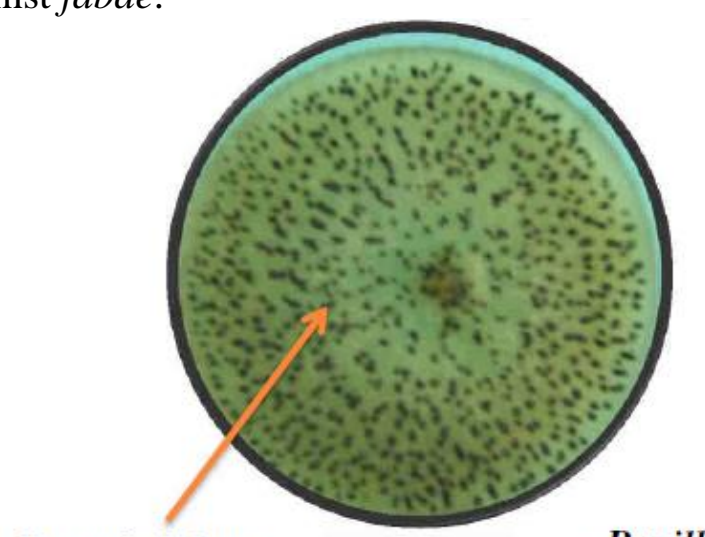

Botrytis fabae

Bacillus subtilis

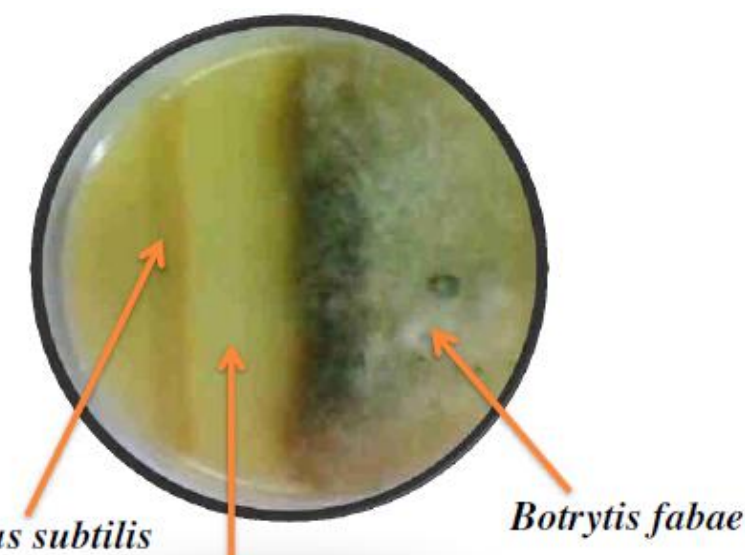

Inhibition zone

Figure1: Antagonistic efficiency of Bacillus subtilis against B.fabae. From this trial they get $62.96 \%$ growth reduction of B.fabae (Kharrat .M, 2015).

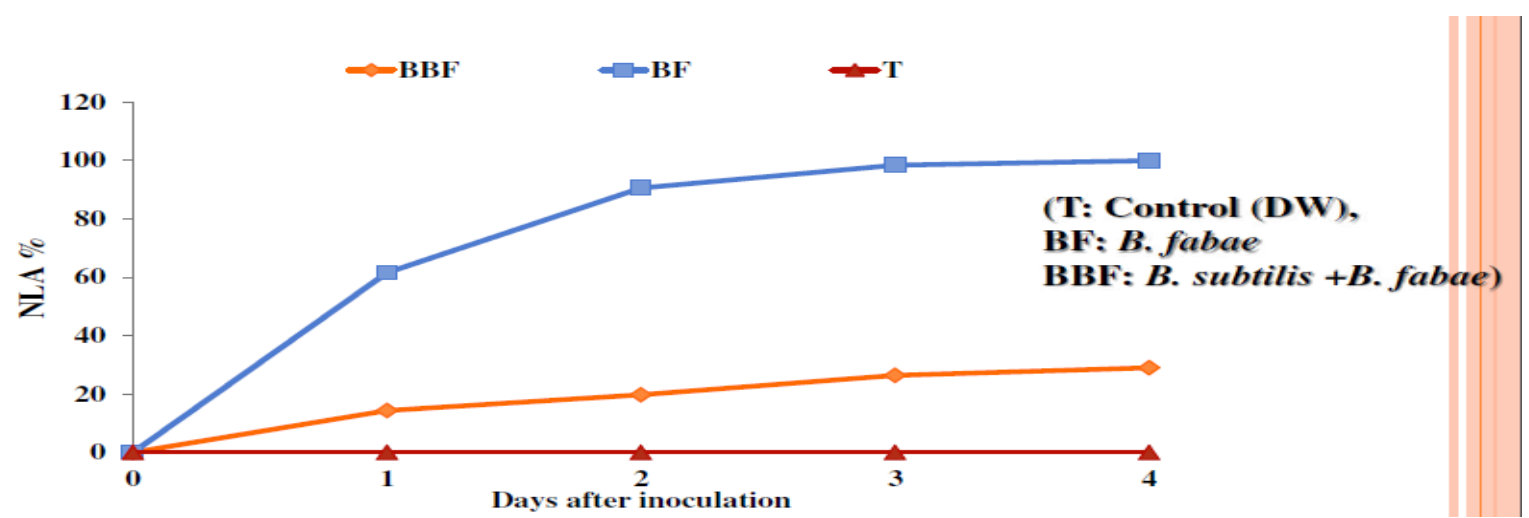

Figure 2: Effect of Bacillus subtilis on chocolate spot disease on detached leaf Also from this trial they found that B.subtilis was efficient in controlling chocolate spot disease (Kharrat. M, 2015). 


\subsubsection{Chemical Control}

Several chemical (fungicides), both systemic and protectant were tested for control of chocolate spot in the past [18]. From these, chlorothalonil, benomyl +mancozeb were effective against chocolate spot. Cholorothalonil completely protected faba bean plants from infection when applied at weekly intervals, but extended intervals more than 15 days were less effective.

Faba bean producers can realize the benefit of early sowing, increased yield, by planting improved varieties at the beginning of the growing season and spraying the crop with chlorothalonil at a rate of $2.5 \mathrm{~kg}$ a.i. per hectare of once or twice after disease infection has reached $30 \%$ severity level [10]. The experiment that were done by using three to four sprays were applied, mancozeb at a rate of $0.7 \mathrm{~kg}$ per hectare proved more effective than chlorothalonil [2].According to the concept of integrated disease management, chemical treatment should only be applied as supplement to combat chocolate spot risk.

\subsubsection{Integrated Disease Management}

These are controlled through the use of Integrated Disease Management (IDM). Used alone, an individual management practice may not reduce the level of disease to an acceptable level, whereas the additive effect of several practices will be done. An integrated approach is the key to successful management of chocolate spot in faba bean. Mixed cropping of faba bean with cereal crops and mancozeb spray reduced the disease and increased the grain yield, as well as the seed weight over sole and mixed cropping with field pea [24, 25]. Similarly [3, 17] also found that cereal mixing with faba bean has advantages over faba bean mixing with field pea. Chocolate spot was significantly reduced when faba bean was intercropped with cereals, but not when intercropped with legumes. Suppressive effects can be ascribed to a combination of host biomass reduction, altered microclimate and physical barriers to spore dispersal. Also creation of a physical barrier in the form of non-host plants prevents some of the dispersed spores from being deposited on the host tissue by interception [22].

Integrated disease control for faba bean studies conducted on farmers' fields under different environmental conditions showed that newly released varieties with resistance to chocolate spot responded less to fungicidal applications. These findings led to the development of improved disease control packages. The use of new, resistant varieties has reduced the use of chemicals drastically [21]. In addition, early sowing, use of improved varieties and fungicide protection avoid the occurrence of chocolate spot disease at epidemic proportions than using the two options individually [16]. With this background Ermiyas and Addisu, 2013 done some research to identifying the best combination of sowing dates and different frequencies of fungicide (Mancozeb) application for the management of chocolate spot disease of faba bean. According to their research out put the mean maximum chocolate spot severity of $51.89 \%$ was recorded from the first sowing date plot that received no fungicide treatment whereas, the least severity of $28.67 \%$ (based on 1-9 scale) was recorded from last sowing date plot which received four times fungicide spray (Table2). 
Table2: Effect of sowing date and fungicide spray frequency on Severity of chocolate spot disease and yield of faba bean

\begin{tabular}{|l|l|l|}
\hline Treatments & Chocolate spot & Yield(Kg/ha) \\
\hline S1C0 & 51.89 & 2960.3 \\
\hline S1C1 & 44.44 & 2895.8 \\
\hline S1C2 & 39.78 & 3009.2 \\
\hline S1C3 & 40.78 & 3527.2 \\
\hline S1C4 & 38.00 & 3903.6 \\
\hline S2C0 & 51.89 & 2498.1 \\
\hline S2C1 & 40.78 & 2864.7 \\
\hline S2C2 & 39.78 & 2904.0 \\
\hline S2C3 & 36.11 & 3051.0 \\
\hline S2C4 & 33.33 & 3320.6 \\
\hline S3C0 & 46.33 & 1927.1 \\
\hline S3C1 & 40.78 & 3110.7 \\
\hline S3C2 & 33.33 & 3039.1 \\
\hline S3C3 & 32.44 & 2255.5 \\
\hline S3C4 & 30.56 & 2930.8 \\
\hline S4C0 & 38.00 & 1275.1 \\
\hline S4C1 & 33.33 & 1810.1 \\
\hline S4C2 & 29.67 & 1504.8 \\
\hline S4C3 & 29.67 & 1558.5 \\
\hline S4C4 & 28.67 & 1606.1 \\
\hline CV & 9.36 & 26.15 \\
\hline LSD $(p<0.05)$ & 0.53 & 1121 \\
\hline & &
\end{tabular}

Note: S1, S2, S3 and S4 = Sowing date 1, 2, 3 and 4. C0, C1, C2, C3 and C4 = Chemical spray frequencies from 0 times spray to 4 times spray. $\mathrm{S} 1 \mathrm{C} 0=$ interaction of Sowing date 1 and 0 times chemical spray, S1C1 = interaction of Sowing date 1 with 1 times chemical spray, S4C4 = interaction of Sowing date 4 with 4 times chemical spray and for all it goes like wise.

Source: Ermiya et al., 2013

From their study they found similar result with what [14] found that is as an effect of integrated use of the three management options; the highest yield (3903.6 kg-1ha) was harvested from plot treated with early sowing and four times fungicide spray. Finally they conclude that adjusted sowing date with resistant variety and judicious use of herbicide can be used as good option of chocolate spot management.

\section{Summary and Conclusion}

The faba bean (Vicia faba) is belonging to tribe Vicieae. It is a legume capable of fixing nitrogen in association with root nodule bacteria and it is the most efficient nitrogen fixer of the pulse crops [24].But, there are many biotic and a biotic factors which hampers faba bean production in Ethiopia. From biotic factors chocolate spot (Botrytis fabae) is the major fungal disease hampering faba bean production in Ethiopia [14, 25]. It is a highly prevalent and destructive 
disease, causing yield loss up to $61 \%$ on a susceptible and $34 \%$ on tolerant faba bean genotypes in the central highlands [14].

We can control the disease by using different methods from these substantial delays and shortening of chocolate spot epidemic and thereby reduction of attack can be achieved by late sowing of faba bean as the conditions suitable for the development of the disease do not exist for a sufficiently long period of time [10]. Also mixed cropping of faba bean with cereal crops and mancozeb spray reduced the disease and increased the grain yield, as well as the seed weight over sole and mixed cropping with field pea [24, 25]. Similarly [3, 17] also found that cereal mixing with faba bean has advantages over faba bean mixing with field pea. Chocolate spot was significantly reduced when faba bean was intercropped with cereals, but not when intercropped with legumes. Suppressive effects can be ascribed to a combination of host biomass reduction, altered microclimate and physical barriers to spore dispersal. Also creation of a physical barrier in the form of non-host plants prevents some of the dispersed spores from being deposited on the host tissue by interception [25]. Integrated disease control for faba bean studies conducted on farmers' fields under different environmental conditions showed that newly released varieties with resistance to chocolate spot responded less to fungicidal applications. These findings led to the development of improved disease control packages.

The use of new, resistant varieties has reduced the use of chemicals drastically [21].In addition, early sowing, use of improved varieties and fungicide protection avoid the occurrence of chocolate spot disease at epidemic proportions [16]. Research done by Ermias and Addisu, 2013 revealed similar result. A fungicide (Mancozeb @ $2.5 \mathrm{~kg} / \mathrm{ha}$ ) was integrated with sowing date and resistant faba bean variety "shalo". As an effect of integrated use of the three management options; the highest yield (3903.6 kg-1ha) was harvested from plot treated with early sowing and four times fungicide spray. Similarly, the highest TKW (543.53 gm.) was also recorded from the plot with the highest yield, which is similar to the result of [14].In general we have to use all available control measure in combination to get a better control of the disease. Also studies which are done in our country and abroad regarding biological control of chocolate disease had shown the possibilities of controlling of B.fabae using some antagonistic fungi and bacteria. Isolate of Trichoderma ovalisporum and Trichoderma longibrachiatum as effective antagonists of $B$. fabae for the first time [25]. In Ethiopia, study has revealed that the biological control agents for chocolate spot of faba bean and Bacilli are natural residents of faba bean leaves. Thirty isolates of Bacillus spp. were tested for their effects on $B$. fabae by dual culture technique on potato dextrose agar.

Sixteen isolates produced $5 \mathrm{~mm}$ or higher inhibition zone and out of these, two isolates were the most effective having inhibition zone of 8 and $7 \mathrm{~mm}$. Isolates reduced the growth of the pathogen colony in dual culture by $23-64 \%$. Four Isolates proved most effective in retarding disease development on two susceptible and one tolerant cultivar and can be further explored for commercial use for management of chocolate spot disease of faba bean [24]. Also study which was conducted by Kharrat Mohamed and by his colic's confirmed that Bacillus subtillis which is gram positive and obligate bacteria had role as biological control against B.fabae. What they do was that they grow the causative pathogen alone and together with the antagonist bacteria on the growth media finally the found that the bacillus have greatest potential to control chocolate spot disease of faba bean so, finally they conclude that B.subtili can be further recommended as 
component of integrated management of chocolate spot disease of faba bean additionally they recommended that, further study has to be done to explore the mode of action by bacillus subtilis against fabae.

\section{References}

[1] Adet Agricultural Research Center (AARC).2001.Progress Report.

[2] Adet Agricultural Research Center (AARC).1996.Progress Report.

[3] Agegnehu, G and Fessehaie, R. 2006. Response of faba bean to phosphate fertilizer and Weed control on nitisols of Ethiopian highlands. Italian J. of Agron. 2: 281-290.

[4] Amare, G.1996. Mixed cropping of faba bean and field pea in Ethiopia. Pp 56-63.In: proceeding of first Agronomy and crop physiology society. Addis Ababa

[5] Berhanu,B.,Kumari,S.G.,Ali,K.,Yusuf,A.,Makkouk,K.M.,Aslake,M.,Ayalew,M.Girma,G. and Hailu,D.2005.Survey of viruses affecting legume crops in Amhara and Oromiya regions of Ethiopia. Phytopathology.Mediterr 44:235-246.

[6] CSA.2014/15.Report on the preliminary results of area, production yields of temporary crops. Central Statistical Authority (CSA), Addis Ababa, Ethiopia.

[7] Dereje G.1999a.Survival of Botrytis fabae Sard. Between Seasons on the crop debris in field soils at Holetta, Ethiopia.Phytopathology.Meditter.38:68-75.

[8] Dereje G. Beniwal, S.P.S. and Tesfaye, B.1987.Screening of faba bean research done on faba bean in Ethiopia for the 1986 crop season.Pp85-94 in IAR Conference papers: Results of research done on faba bean in Ethiopia for the 1986 Crop Season (S.P.S. Beniwal, Ed.).IAR, Addis Ababa.

[9] Dereje G., SPS Beniwal and Alem Berhe.1988.Screening of faba bean lines for chocolate spot and rust resistance. IAR progress reports on faba bean.Pp90-94.

[10] Dereje.G. 1993a.Studies in the epidemiology of chocolate spot (Botrytis fabae sard.) of faba bean. Msc Thesis Alemaya University of Agriculture.

[11] Dereje G. 1996a. Morphological, cultural and pathogenic variability among nine isolates of Botrytis fabae from Ethiopia. FABIS 38/39-41.

[12] Dereje, G. 1999b.Effects of mixed cropping of faba bean and field pea on disease development and yield. Pest management journal of Ethiopia.3 (1 and 2):61-67.

[13] Dereje, G. and Tesfaye, B.1994a.Faba bean diseases in Ethiopia.Pp328-345.In: cool season food legumes of Ethiopia (Asfaw Telaye,Geletu Bejiga,Mohan C.saxena and Mahmud B.Solh.eds.).Proceeding of the first National cool season food legumes Review conference, 16-20 December 1993.Addis Ababa, Ethiopia.

[14] Dereje, G. and Yaynu, H.2001.Yield losses of crops due to plant diseases in Ethiopia. Pest management Journal of Ethiopia5:55-67.

[15] Dereje, G.Mengistu, H. and Tadesse, G.M.1994.Influence of weather factor on infection rate of chocolate spot of faba bean.Pp33-34In: Proceeding of crop protection society of Ethiopia, 26-27 April, 1994.Addia Ababa, Ethiopia.

[16] Dereje, G., Yitbarek, S. and Truwork, A.1993.Screening of faba bean for chocolate spot and rust resistance.Pp60-66 in Research results.1991 crop season. IAR. Addis Ababa, Ethiopia.

[17] Gemechu K., Musa, J. Tezera,W. and Million,B.2006.Faba bean and field pea mixed cropping: Potential and limitations. Research Report No 66.EIAR, Addis Ababa.

[18] Habtu, A. and Dereje, G.1986.Review of pulse disease research in Ethiopia. Page 347-401 In: A review of crop protection Research in Ethiopia. (Tsedeke and Abate, Ed.).Proceeding of the first Ethiopian Protection Symposium,4-7Feb. 1985,Addis Ababa,IAR.Ethiopia.

[19] Jeger, M.J. 2000. Bottlenecks in IPM. Crop Protection 19: 787-792.

[20] Jellis, G.J., Bond, D.A. and Boulton, R.E. 1998. Diseases of faba bean. Pages 371-410. In: The Pathology of Food and Pasture Legumes. (Eds. Allen, D.J. and Lenne, J.M.), CAB International Wallingford, Oxon, UK. 
[21] Khalil, S. A. and Erskine,W. 2001. Combating disease problems of grain legumes in Egypt. Rain legumes No. 32 - 2ndquarter.

[22] Khalil, S.K., Wahab, A., Amanullah, R.A., Amir, Z.K., 2011. Variation in leaf traits, yield and yield components of faba bean in response to planting dates and densities. Egypt. Acad. J. biology. Sci 2(1): $35-43$.

[23] Mesele .H. 2015. Chocolate spot epidemics on different faba bean Varieties and characterization of some botrytis fabae Isolates collected in dawuro zone, southwest Ethiopia. MSc Thesis Jimma University of College of Agriculture and veterinary medicine.

[24] Sahile, S., 2008. The epidemiology and management options of chocolate spot disease (Botrytis fabae Sard.) on faba bean (Vicia faba L.) in Northern Ethiopia. A PhD. Dissertation, Haramaya University, Haramaya, Ethiopia.

[25] Sahile, S., Abang, M.M., Chemeda, F., Seid, A., Sakhuja, P.K., and Baum, M., 2012. Pathogenic and genetic diversity of Botrytis fabae Sand. Isolates from faba bean fields in different agroecological zones of Northern Ethiopia, Archives of Phytopathology and Plant Protection 1, 1- 19.

[26] Wu, T.H. and Lu, J.Y. 1991. A new species of Botryotiniathe teleomorph of Botrytis fabae sardina. Acta Mycologica Sinica 10: 27-30.

[27] Yitbarek, S. 1990.Screening of faba bean for chocolate spot and rust. Page 29-30 in Nile Valley Regional program on Cool Season Food Legumes, Annual Report 1989/90.Ethiopia.ICARDA/NVRP-DOC-001.

*Corresponding author.

E-mail address: misganamitiku441@ gmail.com 